\title{
Responsibilities of Notary Public in Making An Affirmation Deed Amendment of Association
}

\author{
Rafi Lesmana Nanda Yana ${ }^{1} \quad$ Hirsanuddin $^{2} \quad$ Djumardin $^{2}$ \\ 1.Graduate Program Student in Notary, Faculty of Law, Mataram University, Indonesia \\ 2.Lecturer of Faculty of Law, Mataram University, Indonesia
}

\begin{abstract}
The objectives in this study are as follows: (a) to analyze the responsibility of notary public in the creation of an affirmation deed of the amendment of an association. (b) To analyse the legal consequences for a notary public who carries out responsibility for the creation of the affirmation deed of the association's Articles on an unmeticulously and inscrutiny basis. This thesis uses normative research methods, by collecting and analyzing the legal materials in a descriptive order to get an overview or exposure of the problem in the study. The result of this study that the responsibility of the notary in the creation of the deed of either the deed of association, the deed of change or the deed of affirmation, the first is the responsibility in fulfilling the formyl element a deed which means an authentic deed functioning for its complete or perfect (not for the validity of) an act of law, then the act must be set in an authentic. Second, to fulfill the element as a tool of evidence in the day. While the legal consequences for the notary public who carry out duties and responsibilities are not carefully and do not cause a deed has no strength as an authentic deed because it does not fulfill the elements of formyl and proof function, then the notary in question can be held accountable both the civil, criminal and administratively.
\end{abstract}

Keywords: notary, deed, responsibility

DOI: $10.7176 / \mathrm{JLPG} / 98-07$

Publication date:June 30th 2020

\section{INTRODUCTION}

Notary is a general official appointed by the state, working in the interest of the State authorized to make an authentic deed, as far as the creation of such authentic deed is not devoted to other general officials. The creation of authentic deed is required by the legislation in order to create legal certainty, order and legal protection. ${ }^{1}$ Notary Public is running one of the functions of the country, which is to provide state services to the people by providing opportunities to the people to obtain evidence or legal documents related to civil law. ${ }^{2}$

The Legal Notary Tenure gives so much authority to the notary, in addition to the large authority that the notary acquired rights and must carry out the obligations prescribed by the law. One of the rights granted by the law is the right for furlough. However, the right for furlough is not directly obtained by a notary public. It is given to a notary after 2 years term, as stipulated in Article 25 of Law of Notary Tenure (hereinafter referred to as $U U J N)$, stated that:

(1) The notary has a right for furlough

(2) The right of leave as intended in paragraph (1) shall be taken after the notary term for 2 (two) years

(3) During the run of leave, notary obliged to appoint a substitute notary.

Pursuant to the provisions of Article 25 of UUJN above, it is understandable that a notary is entitled to take a furlough, provided that appoints a person to be appointed as a notary public to carry out all obligations, responsibilities and authorities during his/her period of leave. A notary who wants to take the furlough can not simply leave his duties and obligations as a general official, he must continue to provide service to the community, even using a substitute notary.

In Article 1 number (3) UUJN-P governing the notary public stated that:

"The substitute notary is a person who is temporarily appointed as a notary to replace a notary who is on leave, sick, or temporarily unable to run his post as a notary."

A Substitute Notary can only conduct a post as a notary during the period of a notary person who is replaced to be unable to execute his office. Then all authority, obligations and prohibitions applicable to the notarized notary shall also apply to the notary public, as stipulated in Article 33 paragraph (2) of UUJN-P stated:

"The provisions applicable to the notary as referred to in Article 4, Article 15, Article 16, and Article 17 shall apply to the notary public and the provisional Office of notary, unless this law determines otherwise."

The notary ethic code of conduct applies to the substitute notary during his/her position. As stated earlier that the notary has the authority, the same rights and obligations as the notaries are replaced. But in practice, a Substitute is not allowed to carry out some provisions that must be done by a notary person who conducts his/her position as

\footnotetext{
${ }^{1}$ Luthfan Hadi Darus, Hukum Notariat dan Tanggungjawab Jabatan Notaris, UII Press, Yogyakarta, 2017, page 7-8

${ }^{2}$ Habib Adjie, Hukum Notaris Indonesia (Tafsir Tematik Terhadap UU No. 30 Tahun 2004 tentang Jabatan Notaris), PT Refika Aditama, Bandung, 2008, (Selanjutnya disebut Habib Adjie I), page 78
} 
specified in Article 3 figure (9) Notary Code of Ethics stated:

"Notary and other person who held the office and run a compulsory notary:... Install 1 (one) name board in front/in the office environment with the choice of size $100 \mathrm{~cm}$ x $40 \mathrm{~cm}, 150 \mathrm{~cm}$ x $60 \mathrm{~cm}$ or $200 \mathrm{~cm} \times 80 \mathrm{~cm}$, which contains:

a. Full name and valid title name;

b. Date and number of last appointment letter as notary;

c. place of position;

d. Office address and telephone/fax number.

e. The base of the white signboard with black letters and the writing on the nameplate should be clear and readable. Except in the office environment it is not possible to install the nameplate."

Referring to Article 33 paragraph (2) UUJN-P and Article 1 number (2) Notary Code of conduct, the substitute notary is authorized by the law to carry out all rights and obligations relating to the implementation of the notary office, both chapters do not clearly indicate the limitation of the substitute in the position of the post on what can be done and should not be done by the substitute so that there is generally a blurring of the norm in Article 33 paragraph (2) UUJN-P. Because in the Article there is no limitation of authority for a substitute notary and give rise to the pros and cons in the notary public in interpreting the intent of the Article so as to cause disagreements. If viewed explicitly from the Article then the substitute is entitled to implement its authority based on the provisions of UUJN and notary code of ethics without any limitation, but in the implementation of a notarized substitute limited authority in several ways as described above so there is a difference between das sein and das sollen. This needs to be done research to assess what is not allowed and can be done by a notary public because until now there is no Article or rule that prohibits and restricts the authority, rights, and obligations of a notary public during the term of his office in West Lombok regency with the number of the notary who is currently held 40 notary people so that in the future a substitute notary position get the Clarity

\section{RESEARCH METHOD}

This type of research used in legal research is normative. The approach used in this research is the Statue approach, conceptual approach, the type of data used in this research is primary data, namely data from social facts related to the work of real law encountered by researchers. Secondary Data, namely departing from social facts referenced from books, research results and scientific journals. Used as a result data that supports primary data in the discussion and analysis process. ${ }^{1}$ The legal materials used in this research are primary legal materials are binding legal materials, and consist of statutory regulations. Secondary legal material is a legal material that provides explanations about the primary legal material, such as the draft law, research results, works from the law, and so on. ${ }^{2}$ Tertiary legal materials are materials that provide instruction as well as explanations of primary and secondary legal materials; Examples are the legal dictionary, the Encyclopedia, the cumulative index, and so on.

The techniques used in collecting the data and the legal materials are in normative legal studies, data collection techniques are conducted with the study of libraries on primary legal materials, secondary legal materials, as well as tertiary legal materials and/or non-legal materials. The search for the legal materials can be done by reading, viewing, listening, or now many of the transmission of legal materials through the Internet. ${ }^{3}$

\section{DISCUSSION}

\section{Notary Liability In The Creation Of The Deed}

Legality of Notarial Deed

The legality of the deed in the legal relationship is very important, especially in the civil relations of the parties. Not only as a legal basis for acting but also as a perfect evidence between the two of the aspects of its evidences. So that the existence of third parties authorized by legislation to pour (to consolidate) the deed of the parties has the important meaning also to ensure the legal certainty. Notary in his position to serve the interests of the public, help to create certainty and provide legal protection to members of the community in accordance with the law.

The Constitution of the Republic of Indonesia year 1945, in Article 28 D paragraph (1) mentioned that "Everyone has the right to acknowledgment, guarantee, protection, and fair legal certainty and the same treatment is faced by the law". Ensuring the certainty, order, and protection of the law is required an authentic written proof tool of the conduct, agreements, assignments, and legal events made in advance or in the presence of a notary. ${ }^{4}$ The assurance and legal protection of the deeds of the parties, make the notary important, especially related to the assurance of assurance and protection of the deed of the parties made, both in terms of formal function and the function of proving the deed.

\footnotetext{
${ }^{1}$ Mukti Fajar ND dan Yulianti Achmad, Dualisme Penelitian Hukum Normatif \& Empiris, Pustaka Pelajar, Yogyakarta, 2015, page 59.

${ }^{2}$ Soerjono Soekanto, Pengantar Penelitian Hukum, UI Press, Jakarta, 2006, page 52.

${ }^{3}$ Mukti Fajar ND dan Yulianti Achmad, Op. Cit., page 160

${ }^{4}$ General explanation of the Law of the Republic of Indonesia Number 2 year 2014 concerning amendment to law number 30 year 2004 on Notary Department, Page 1
} 
Notarial Deed Function

For those interested parties and their heirs or for those who have the right to them, an authentic deed provides a perfect proof of what is contained therein (Article 1870 of Civil Law) and provisions in UUJN, the position of deed becomes very important in relation to the aspect of proving the proceedings in the proceeding, in relation to the provisions contained therein therefore, the authority of the official for its creation and its ordinances. According to Sudikno Mertokusumo explained there are 2 (two) functions of authentic deeds are:

1. Formil function (causa formality) which means an authentic deed functioning for its complete or perfect (not for the validity of) an act of Law, the Act of law must be poured out in an authentic deed, so that the deed is the formyl requirement for a legal act.

2. The function of evidence (the Probationis causa) that an authentic deed is made deliberately to be proven in the present day, the written nature of an agreement in the form of authentic deed does not make the agreement, but can only be used as a tool of evidence in the day. ${ }^{1}$

Types of Notarial Deed

Notary Authority contained Article 15 UUJN, paragraph (1) UUJN asserted that one of the authorities of notary, namely to make the deed in general, with the limitation ${ }^{2}$ :

1. Not excluded to other officers stipulated by law.

2. Concerning the deed to be made or authorized to make an authentic deed of all the deeds, agreements, and provisions required by the rule of law or required by the concerned.

3. Regarding the legal subject (person or legal entity) for the benefit of whom the deed is made or required by the interested.

4. Authorities on the place, where the deed is made, it is in accordance with the position and the territory of the notary public.

Provisions contained in UUJN in terms of form and nature as in Article 38 UUJN is a formal source of notarial deed is also the legality of the existence of notarial deed as an authentic deed, with the terms of a deed. ${ }^{3}$

The types of deeds consist of two kinds:

1. Deed is made by the official, referred to by the deed of Relaas Deed or Officials Deed (ambtelijke akten), for example: Deed of Treatise of the Limited company meeting made by notary; News opening event Safe-deposit box of a limited banking company; News of the raffle draw;

2. Deed is made in the presence of officials, which is often referred to by the party deed (partij acten), for example lease agreements on the land following the building of members of the community, Trading Deed, Money Grant Act, Wills Deed, Authorization letter and others. In the deed the parties are listed as a description of the persons acting as parties in the deed. ${ }^{4}$

Legal Relationship Between Notary and The Parties

The legal relationship between the notary and the party who comes to the notary is a legal relationship that has a distinctive character as follows: ${ }^{5}$

1. There is no need for an agreement whether oral or written in the form of authorization to make a deed or to do certain occupations.

2. Those who comes to the notary, assuming that the notary has the ability to help formulate the wishes of the parties in writing in the form of authentic deed.

3. The final result of the notary action is based on notary authority derived from the requests or wishes of the parties themselves, and

4. Notary is a Non-party in the deed concerned.

According to the opinion that the legal relationship between the notary and the parties is not a legal relationship that as in the law of the Agreement such as the achievement of the promised or the demands of tort and or the relationship of a contractual nature.

Until today in Indonesia, especially among the notary public is still embraced that the notary accountability in relation to the party who cmes to the nootary, along with the UUJN, is also based on acts against the law and tort. $^{6}$

The essence of an act against the law or violating the law (onrechtmatige daad), namely no contractual relationship between one party and the other. Actions against the law can occur one party detrimental to the other

\footnotetext{
${ }^{1}$ Sjaifurrachman \& Habib Adjie, Aspek Pertanggungjawaban Notaris Dalam Pembuatan Akta, Mandar Maju, Bandung, 2011 , page 114-115.

${ }^{2}$ Ibid page 8-9

${ }^{3}$ Loc. Cit, page 37

${ }^{4}$ Yenny Lestari Winamarta, "notary secret, and legal protection for notary Public (secret) deed" (thesis, Faculty of Law, notary University of Indonesia 2011), page 17.

${ }^{5}$ Ibid

${ }^{6}$ Habib Adjie (IV) “Merekontruksi : Hubungan Hukum Notaris Dan Penghadap/Para Penghadap” page1. Link: http://habibadjie.dosen. narotama. ac.id/files /2013/07/ REKONTRUKSI-PENGHADAP.pdf, Accessed on Monday, 15 Februari 2020.
} 
without an accident but inflict harm on either party. ${ }^{1}$

Minuta Deed

Due to minuta deed relating to approval letter in taking minuta deed and calling notary in the judicial process as provision of Article 66 UUJN. It will be outlined in relation to the " minuta deed ": The Minuta Deed is the original act which includes the signatures of the complainers, witnesses, and notaries, which is stored as part of the notary protocol. $^{2}$

\section{Legal Consequences For A Notary Who Performs The Duties And Responsibilities Of The Deed In An Uncareful And Thorough}

Notary Authority in the Making of Deed

Any authority which is given to the office must be based on its legal rule as a limitation for the office to run properly and not to collide with the authority of other departments. Thus, if an official (notary) performs an action outside the prescribed authority, it can be categorized as an act of violating the authority.

According to Philipus M. Hadjon, there is a term of authority that is parallel to the legal term in Dutch, Bevoegheid. There is a slight difference between the three terms, the difference lies in the legal character. The term Bevoegheid is used both in the concept of public law and the concept of private law. ${ }^{3}$

Duties and authorities of notary public shall be governed by Article 1 digit 1 of UUJN, which is to create an authentic deed and other authority as referred to in UUJN. Other notary authorities are included in Article 15 paragraph (1), (2), and (3) Amendment.

\section{Notary Liability}

Notary liability in civil is a form of responsibility that a person takes to a party that has been harmed. O. P. Simorangkir directly argues that the responsibility of the obligation to bear or to the responsibility of all duties, with all views from good or bad measure, the responsibility is to be responsible for the consequences of the adverse action performed. ${ }^{4}$

The responsibility of the notary in carrying out his position may be interpreted that the notary shall enforce the provisions of the UUJN. The notary is responsible for carrying out the Authority pursuant to Article 15 of the amendment, carrying out a notarized obligation of Article 16 of the amendment and making the deed authentic pursuant to the provisions of chapter VII UUJN on the authentic deed.

\section{Criminal Notary Liability}

Criminal Notary Liability contains a principle of error (Principle of refactility), which is based on a monodualistic balance that the principle of error based on the value of justice must be aligned in pairs with the legality principle based on the value of certainty. Although the concept believes that criminal liability is based on mistakes, but in some cases it does not close the possibility of a vicarious liability and strict liability (strict liability). Error problems (errors) about the situation (Error facti) and misguidance about the law in accordance with the concept is one reason forgiving so that the perpetrator is not sentenced unless his fault is to blame for him. ${ }^{5}$

Criminal responsibility is a mechanism to determine whether a person is a defendant or suspected to be accountable for a criminal act or not. To be able to do the perpetrator, it is required that the criminal act is fulfilled to the elements that have been prescribed in the law.Criminal liability implies that any person who commits a criminal offence or against the law, as formulated in the law, then that person should responsible in accordance with their mistakes. In other words, people who commits criminal act will answer the act by criminal when he/she has a mistake, someone has an error when at the time of doing the act seen in terms of society shows a normative view of the mistakes that the person has done. ${ }^{6}$

Criminal liability is applied with the criminal enforcement, which aims to prevent the crimes from committing by enforcing the legal norm for the sake of Community stewardship; resolve any conflicts inflicted by criminal acts; restoring balance; Bring a sense of peace in society; Socialize criminal by conducting coaching so that it becomes a good person and liberates guilt on the convicted.

The administrative of legal responsibilities of the notary

The administrative of legal responsibilities of the notary can be seen from the sanction which is given for violation

\footnotetext{
${ }^{1}$ Ibid

${ }^{2}$ Article 1 number 8 UUJN.Philipus M. Hadjon, about authority, Yuridika, Faculty of Law of Universitas Airlangga, No. 5 San 6, year XII, September-December 1997, p. 1, as quoted back by Habib Adjie (V), civil and administrative sanctions against notaries as public officials, third print, Refika Aditama, Bandung, 2013, pages 33

${ }^{3}$ Ibid

${ }^{4}$ O.P. Simorangkir, Etika Jabatan, Aksara Persada Indonesia, Jakarta, 1998, page 102.

${ }^{5}$ Barda Nawawi Arief, Masalah Penegakan Hukum Dan Kebijakan Penanggulangan Kejahatan, PT. Citra Aditya Bakti, Bandung, 2001, page 23

${ }^{6}$ Moeljatno, Perbuatan Pidana Dan Pertanggung Jawaban Dalam Hukum Pidana, Bina Aksara, Jakarta, 1984, page 41
} 
of the obligations imposed on the notary public. Article 16 paragraph (11) UUJN A change that reads:

Notarized notary Provisions as intended in paragraph (1) letter A to letter L may be subject to sanctions in the form of:

a. Written warning;

b. Temporary dismissal;

c. Termination with respect; Or

d. Termination with unrespect.

As for Article 16 paragraph (1) reads, In carrying out his office, notary mandatory:

a. Acting trustful, honest, equitable, independent, immoral, and safeguard the interests of the parties concerned in the act of law;

b. Create a deed in the form of a Minuta deed and store it as part of the notary protocol;

c. Attach letters and documents as well as a fingerprint on the Minuta deed;

d. Issuing the Grosse deed, a copy of the deed, or the deed based on Minuta deed;

e. Provide services in accordance with the provisions of this law, unless there is a reason to reject it;

f. Keep confidential everything about the deed, and any information obtained in order to make the deed in accordance with the oath/pledge, unless the law determines otherwise;

g. Bind the deed made in 1 (one) month into a book that contains no more than 50 (fifty) Act, and if the number of the deed could not be contained in a single book, the Act may be bound into more than one book, and records the number of the deed Minuta, month, and year of its creation on the cover of each book;

h. Make a list of the act of protest against unpaid or unreceived securities;

i. Make a list of acts relating to wills in the order of the preparation time of the Act every month;

j. Submit a list of the deed as referred to in letter I or a register of law in respect of a will to the center of Wills in the Ministry that conducts government affairs in the field of laws within 5 (five) days of the first week of the following month;

k. Records in the Repertorium the date of submission of wills at the end of each month;

1. Have a stamp or stamp that contains the symbol of the Republic of Indonesia and in the space that it is marked is written name, title, and place of position concerned;

$\mathrm{m}$. Read the deed in the presence of the roadblock by being attended by at least 2 (two) witnesses, or 4 (four) special witnesses to the creation of the private deed, and signed at that time also by the appearers, witnesses, and notary; and

n. Receive a Notary candidate internship.

\section{CONCLUSION}

That the responsibility of notary in the creation of deed whether it is deed establishment, the deed of Change or the first affirmation deed: is in relation to the responsibility in fulfilling the Formil (causa formality) a deed which means an authentic deed functioning for its complete or perfect (not for the validity of) an act of Law, the Act of law must be poured out in an authentic deed, so that the deed is the formyl requirement for a legal act. Secondly, to observe the element as a tool of evidence (the probationis causa) that an authentic deed is made deliberately to be proof in the days, the written nature of a treaty in the form of authentic deed does not make the agreement, but can only be used as a tool of evidence in the day.

That the legal consequences for a notary who performs the duties and responsibilities is not carefully and inscrutiny that causes a deed has not has the power as an authentic deed so as not to fulfill the formyl elements and proof function, then the notary in question can be held accountable both the civil, criminally and administratively.

\section{REFFERENCES}

Habib Adjie, 2008, Hukum Notaris Indonesia (Tafsir Tematik Terhadap UU No. 30 Tahun 2004 tentang Jabatan Notaris), PT Refika Aditama, Bandung.

Philipus M. Hadjon, Tentang Wewenang, Yuridika, Fakultas Hukum Universitas Airlangga, Nomor 5 dan 6, Tahun XII, September Desember 1997.

Sjaifurrachman dan Habib Adjie. Aspek Pertanggungjawaban Notaris Dalam Pembuatan Akta. Bandung: Mandar Maju, 2011.

O.P. Simorangkir, Etika Jabatan, Aksara Persada Indonesia, Jakarta, 1998.

Barda Nawawi Arief, Masalah Penegakan Hukum Dan Kebijakan Penanggulangan Kejahatan, PT. Citra Aditya Bakti, Bandung, 2001.

Mukti Fajar ND dan Yulianti Achmad, 2015, Dualisme Penelitian Hukum Normatif \& Empiris, Pustaka Pelajar, Yogyakarta.

Salim HS dan Erlies Septiana Nurbani, 2014, Penerapan Teori Hukum Pada Penelitian Tesis dan Disertasi, PT. RajaGrafindo Persada, Jakarta.

Soerjono Soekanto, 2006, Pengantar Penelitian Hukum, UI Press, Jakarta. 
Moeljatno, Perbuatan Pidana Dan Pertanggung Jawaban Dalam Hukum Pidana, Bina Aksara, Jakarta, 1984.

Indonesia, act No. 2 of 2014 on the amendment to law No. 30 of 2004 on the Department of notary. State Gazette of the Republic of Indonesia 2004 No. 3. Additional State Gazette of the Republic of Indonesia No. 5491

Yenny Lestari Wilamarta, "Rahasia Notaris, Hak Ingkar Dan Perlindungan Hukum Bagi Notaris Yang Membuka Isi (Rahasia) Akta" (Thesis, Faculty of Law of Magister Kenotariatan University of Indonesia 2011).

Habib Adjie, "Merekontruksi : Hubungan Hukum Notaris Dan Penghadap/ Para Penghadap", http://habibadjie.dosen. narotama. ac.id/files /2013/07/ REKONTRUKSI-PENGHADAP. pdf. 